\title{
FIRST RECORD OF TRIAENODES BICOLOR (CURTIS, 1834) (INSECTA: TRICHOPTERA) FROM THE ECOREGION HELLENIC WESTERN BALKANS
}

\author{
Halil Ibrahimi ${ }^{1}$, Ruzhdi Kuçi ${ }^{2 *}$, Astrit Bilalli ${ }^{3}$ \& Ermira Gashi ${ }^{1}$ \\ ${ }^{1}$ Department of Biology, Faculty of Mathematical and Natural Sciences, University of Prishtina \\ "Hasan Prishtina", "Mother Theresa" p.n., 10000 Prishtinë, Republic of Kosovo \\ ${ }^{2}$ Faculty of Education, University of Prishtina "Hasan Prishtina”, “Mother Teresa” p.n., \\ 10000 Prishtinë, Republic of Kosovo \\ ${ }^{3}$ Faculty of Agribusiness, University of Peja "Haxhi Zeka", “UÇK” street, 30000 Pejë, \\ Republic of Kosovo
}

Ibrahimi, H., Kuçi, R., Bilalli, A. \& Gashi, E.: First record of Triaenodes bicolor (Curtis, 1834) (Insecta: Trichoptera) from the Ecoregion Hellenic Western Balkans. Nat. Croat., Vol. 26, No. 2., 197-204, Zagreb, 2017.

We collected adult caddisfly specimens with entomological nets and ultraviolet light traps monthly from May to November 2012 in Brezne Lake situated in Dragash Municipality. During this investigation we found the Leptocerid species Triaenodes bicolor for the first time in Kosovo; it is also the first record for Ecoregion 6, Hellenic Western Balkans. Additionally, this is the first record of the genus Triaenodes from Kosovo. In total seven males and three females of this species were found. Triaenodes bicolor is present all over the European continent but has been rarely sampled in southeastern Europe. Other taxa sympatric with Triaenodes bicolor in the investigated locality are: Hydropsyche instabilis, Hydropsyche spp., Plectrocnemia conspersa, Plectrocnemia spp., Micropterna nycterobia, Micropterna sequax, Limnephilus vittatus, Limnephilus auricula and Thremma anomalum.

Keywords: Triaenodes, Kosovo, Trichoptera, Balkan Peninsula

Ibrahimi, H., Kuçi, R., Bilalli, A. \& Gashi, E.: Prvi nalaz vrste Triaenodes bicolor (Curtis, 1834) (Insecta: Trichoptera) iz Ekoregije helenski zapadni Balkan. Nat. Croat., Vol. 26, No. 2., 197-204, Zagreb, 2017.

Odrasli oblici tulara su sakupljeni entomološkom mrežom i ultraljubičastom svjetlosnom klopkom od svibnja do studenog 2012. godine na jezeru Brezna u Općini Dragaš. Tijekom ovog istraživanja, vrsta iz porodice Leptoceridae Triaenodes bicolor nađena je po prvi puta na Kosovu i u Ekoregiji 6 (helenski zapadni Balkan). Istovremeno, ovo je prvi nalaz roda Triaenodes s Kosova. Ukupno je nađeno sedam mužjaka i tri ženke ove vrste. Vrsta Triaenodes bicolor rasprostranjena je na cijelom europskom kontinentu, ali je rijetko zabilježena u jugoistočnoj Europi. Ostale simpatrične vrste uz vrstu Triaenodes bicolor na istraživanom lokalitetu su: Hydropsyche instabilis, Hydropsyche spp., Plectrocnemia conspersa, Plectrocnemia spp., Micropterna nycterobia, Micropterna sequax, Limnephilus vittatus, Limnephilus auricula i Thremma anomalum.

Ključne riječi: Triaenodes, Kosovo, Trichoptera, Balkanski poluotok

\section{INTRODUCTION}

Leptoceridae is one of the largest caddisfly families, with more than 1,500 species in around 50 genera (Morse, 2016). Known otherwise as 'long horned caddisflies' because of their extraordinarily long antennae, they are present in a variety of habitats, from slow flowing rivers to cold and rapidly flowing streams, including temporary waters and even saline lakes (ST. CLAIR, 1994). Most species

\footnotetext{
*Corresponding author: ruzhdi.a.kuqi@hotmail.com
} 
of this family are univoltine but semivoltine and multivoltine cases have been registered within the family (Graf et al., 2008).

The genus Triaenodes McLachlan, 1865 has a cosmopolitan distribution and contains nearly 300 species (Morse, 2016; OlÁH, 2016). There are only four taxa present in Europe: Triaenodes bicolor (Curtis, 1834), Triaenodes ochreellus ochreellus McLachlan, 1877, Triaenodes ochreellus lefkas Malicky, 1974 and Triaenodes unanimis McLachlan, 1877. Triaenodes unanimis is mostly distributed in Western and Eastern Europe, T. bicolor is present in the whole continent, T. ochreellus ochrellus was so far only found in ecoregions 1, 2, 8 and 13 and T. o. lefkas in ecoregions 3, 5 and 6 (Graf et al., 2008).

Larvae of species of the genus Triaenodes inhabit lentic and lotic waters, where they are closely associated with the aquatic vegetation. As in many other leptocerid species, the larvae of Triaenodes bicolor have extremely elongated posterior legs with concentrations of setae on the femur, tibia and tarsus, known as swimming hair. This modification in legs enables them to swim among aquatic plants in search of food (GALL et al., 2011).

The goal of this paper was to study the diversity of the caddisfly fauna of Brezne Lake and consequently contribute to the faunistic list of the Republic of Kosovo. A specific goal of this investigation was also to contribute to the knowledge on the distribution of the genus Triaenodes in southeastern Europe, including some ecological notes and data on its habitat.

\section{MATERIAL AND METHODS}

\section{Data sampling and processing}

Adult caddisfly specimens were collected with entomological net and ultraviolet light trap. The sampling was carried out monthly from May to November 2012. Ultraviolet light was placed above a white pan of $60 \mathrm{~cm}$ in diameter, filled with water and a few drops of detergent. The light trap was placed on the stream bank and operated from dusk until next morning. Collected samples were preserved in $80 \%$ ethanol. The specimens were identified under a stereomicroscope with determination keys from Malicky $(2004)$ and Kumanski $(1985,1988)$. Female specimens of the genus Hydropsyche Pictet, 1834 are identified only up to the generic level due to the difficulties in identifying the species accurately. One female specimen of the genus Plectrocnemia Stephens, 1836 is also identified only to the generic level due to the slight damage of terminal part of genitalia. However, it does not belong to Plectrocnemia conspersa (Curtis, 1834) which was also collected at this locality.

The collection is deposited at the Laboratory of Zoology of the Faculty of Mathematics and Natural Sciences, University of Prishtina "Hasan Prishtina", Republic of Kosovo.

\section{Study area}

The sampling site is located at Brezne Lake in Brezne village of Dragash Municipality. The lake is located at the foothills of Koritnik Mountains and is a relic of a previously bigger lake that covered the Llapushnik valley. Its total length is about $250 \mathrm{~m}$, width $100 \mathrm{~m}$ and maximal depth about $10 \mathrm{~m}$. The lake is fed by surface and underground waters. A small stream coming from Plavë village also discharges into this lake. The substrate is mostly dominated by silt, but there are stones of different sizes as well, especially around the area of the streamlet.

The sampling site (Fig. 1, Fig. 2) is located at the western side of the lake, about 100m in distance from the brook $\left(42.130913^{\circ} \mathrm{N}, 20.640791^{\circ} \mathrm{E}\right.$, and $947 \mathrm{~m}$ above sea level).

\section{RESULTS AND DISCUSSION}

During this investigation we employed two methods for collecting caddisflies: entomological nets and ultraviolet light traps. Several studies in the area (e.g. IвRAнIмi et al., 2014a, 2014b, 2015a, 2015b; StANićKoštroman, 2009) have emphasized the importance of using both methods in sampling caddisflies in order to get the real number of species present, due to the fact that within this order of aquatic insects there are species with different ecological habits and flight activity. This was borne out during this investigation, in which some species were sampled only with certain method. During the seven-month period of investigation, twelve taxa were collected in total (Tab. 1) with both methods; they belonged to the following five families: Hydropsychidae, Limnephilidae, Polycentropodidae, Leptoceridae and Uenoidae. 


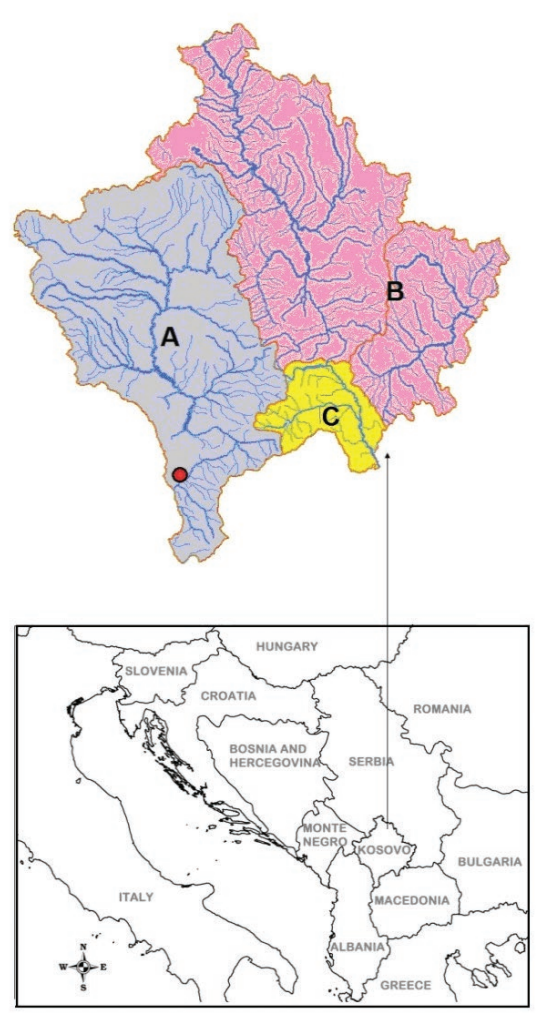

The highest number of species belongs to the family Limnephilidae, six in total. Species of this family are found to dominate in other lakes of similar size in Europe as well (e.g. Kiss et al., 2003). Other families found during this investigation are also common for standing waters. Most of the species found during this investigation are commonly found in southeastern Europe and Kosovo as well with the exception of all species of the genus Limnephilus Leach, 1815 which are quite rare in Kosovo according to the current knowledge. The only species of the family Uenoidae found during this investigation, Thremma anomalum, is not a species commonly found in lakes and we presume the habitat of larvae of this species is the nearby stream which discharges into the lake.

In total ten species belonging to all five families were collected with entomological nets during this investigation. In total ten species were also collected with ultraviolet light traps during the same period; they belonged to the following families: Hydropsychidae, Limnephilidae, Polycentropodidae and Uenoidae. However, Limnephilus sparsus Curtis, 1834 and Limnephilus vittatus Curtis, 1834 were collected only with the ultraviolet light trap. These two species are mostly active during the night, spending the day and especially the warm hours hidden within the leaves of quite high trees (e.g. GAsHI, 2014).

Triaenodes bicolor was sampled twice during this period and only with an entomological net. The first sampling of this species was on $15^{\text {th }}$ of July 2012 and

Fig. 1. Sampling site in Brezne Lake with indicated watersheds in the Republic of Kosovo: A - Adriatic Sea Basin, B - Black Sea Basin, C - Aegean Sea Basin.

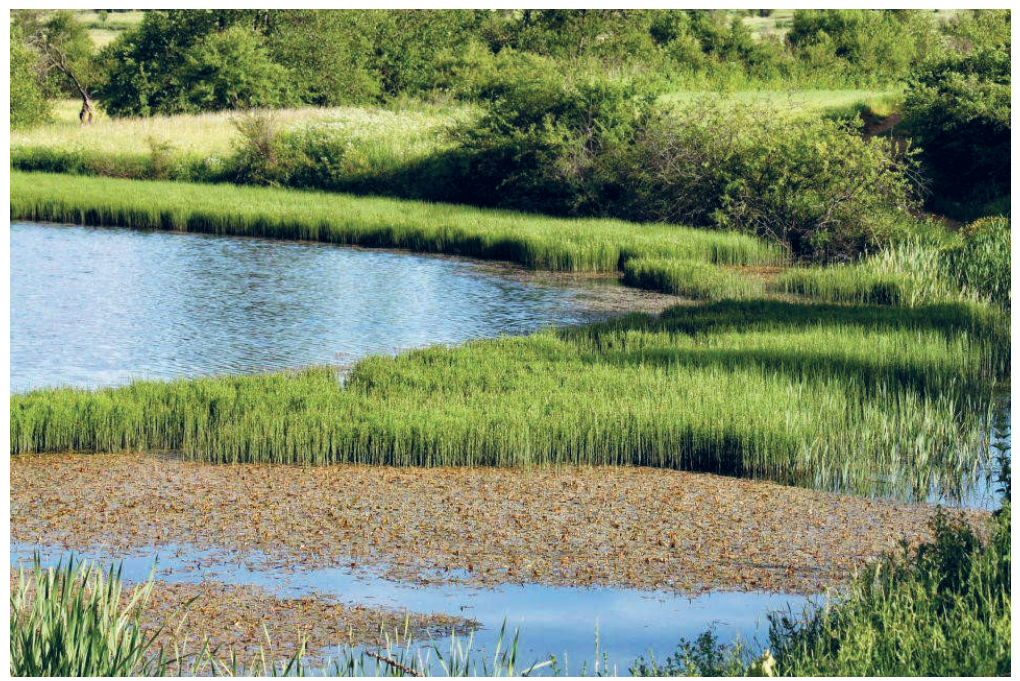

Fig. 2. Sampling site at Brezne Lake. 
the second and last one was on $3^{\text {rd }}$ of August 2012. Apparently T. bicolor is active during the night as well although the number of sampled specimens with ultraviolet light traps in other similar studies is very low compared to some other species of the family Leptoceridae for example (Higler et al., 2008). Since there are no comparable results for collecting caddisflies with both methods elsewhere and which include this species, we can only suppose that the reason why this species is sampled only with an entomological net during our investigation lies only on its low population density. This is supported by the low number of individuals sampled with an entomological net as well: only ten individuals during a one year sampling period.

This investigation shows that the application of different sampling techniques results in discovery of more species and especially those with small populations which are usually overlooked when only one particular method in collecting caddisflies is used.

This is the first record of Triaenodes bicolor for the Republic of Kosovo and Ecoregion 6, Hellenic Western Balkans (IlLIEs, 1967). This is at the same time the first country record of the genus Triaenodes. Previously this species has been recorded across most of Europe, except in the southern ecoregions ER1, 2, 6 (Iberic-Macaronesian ecoregion, the Pyrenees, Hellenic Western Balkans) and Iceland (ER19) (GrAf et al., 2008). The species seems to be very rare in Kosovo. More than 200 localities in lakes, streams and rivers all over Kosovo were surveyed during the nine year period (2008 - 2016) for Trichoptera (e.g. Gashi et al., 2015; Gashi \& Ibrahimi, 2008; Ibrahimi et al., 2014a, 2014b, 2015a, 2015b, 2016a, 2016b; Oláh et al., 2014, 2015) and Brezne Lake is the only locality where this species has been found so far. Notwithstanding a few records in Slovenia (URBANIČ, 2001) and Bulgaria (KUMANSKI, 1985), the species seems to be almost completely absent from southeastern Europe according to the current knowledge (DAET, 2017; Fig. 3). Despite several earlier investigations in Greece, Bosnia and Herzegovina, Croatia, Montenegro and Serbia, it has not been found so far in these countries (e.g. MARinković-Gospodnetić, 1966, 1970, 1971, 1975, 1978, 1980; Kučinić et al., 2012, 2015; Malicky, 2005; STANić-Koštroman, 2009; Žıvič et al., 2006). It is highly probable that the species is present elsewhere in southeastern Europe, but with a limited distribution, reflecting the preferred habitats of this species in this part of Europe. Triaenodes bicolor is a phytal habitat specialist and warm water stenotherm. In addition to this, most of the studies investigating caddisflies of this part of Europe are focused on streams and rivers, while standing waters are only rarely investigated. In neighbouring Albania another species of Triaenodes has been found, Triaenodes ochreellus with subspecies

1676 Triaenodes bicolor (CURTIS, 1834)

LEPTOCERIDAE

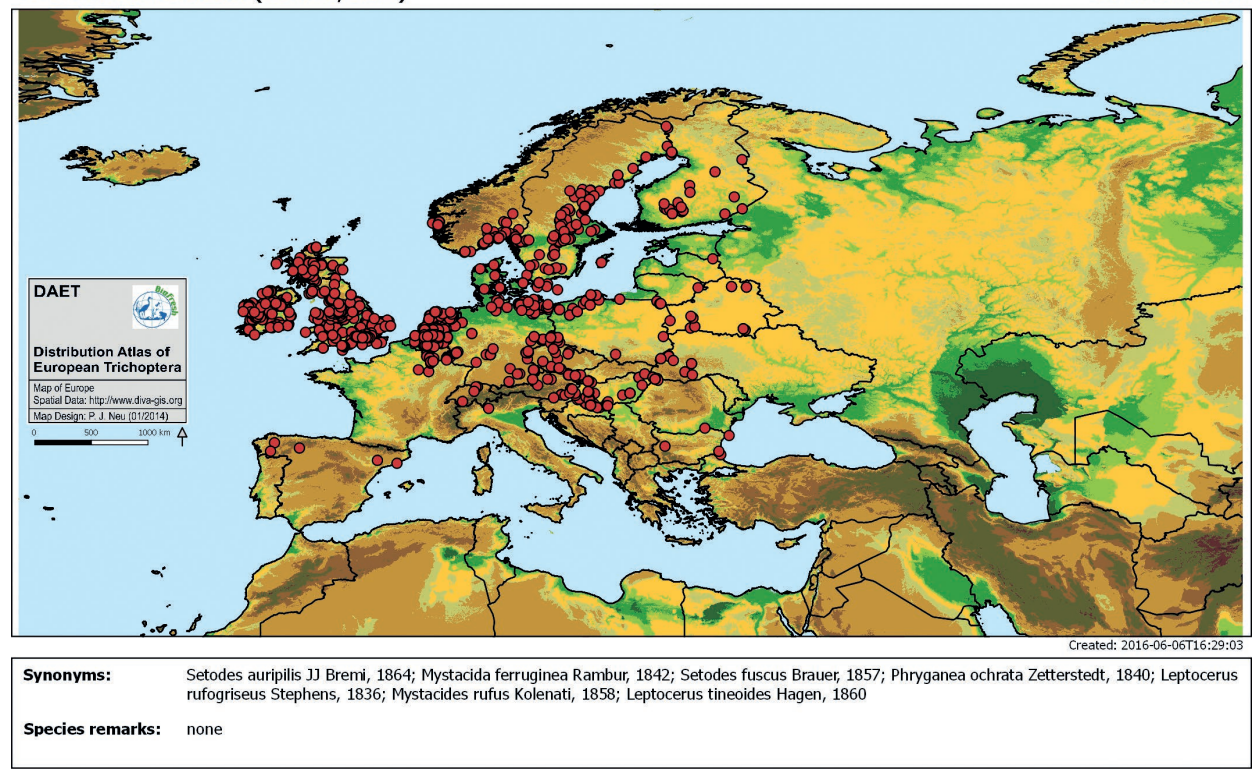

Fig. 3. Distribution of Triaenodes bicolor in Europe, prior to the current investigation, according to the Distribution Atlas of European Trichoptera (DAET, 2017). 


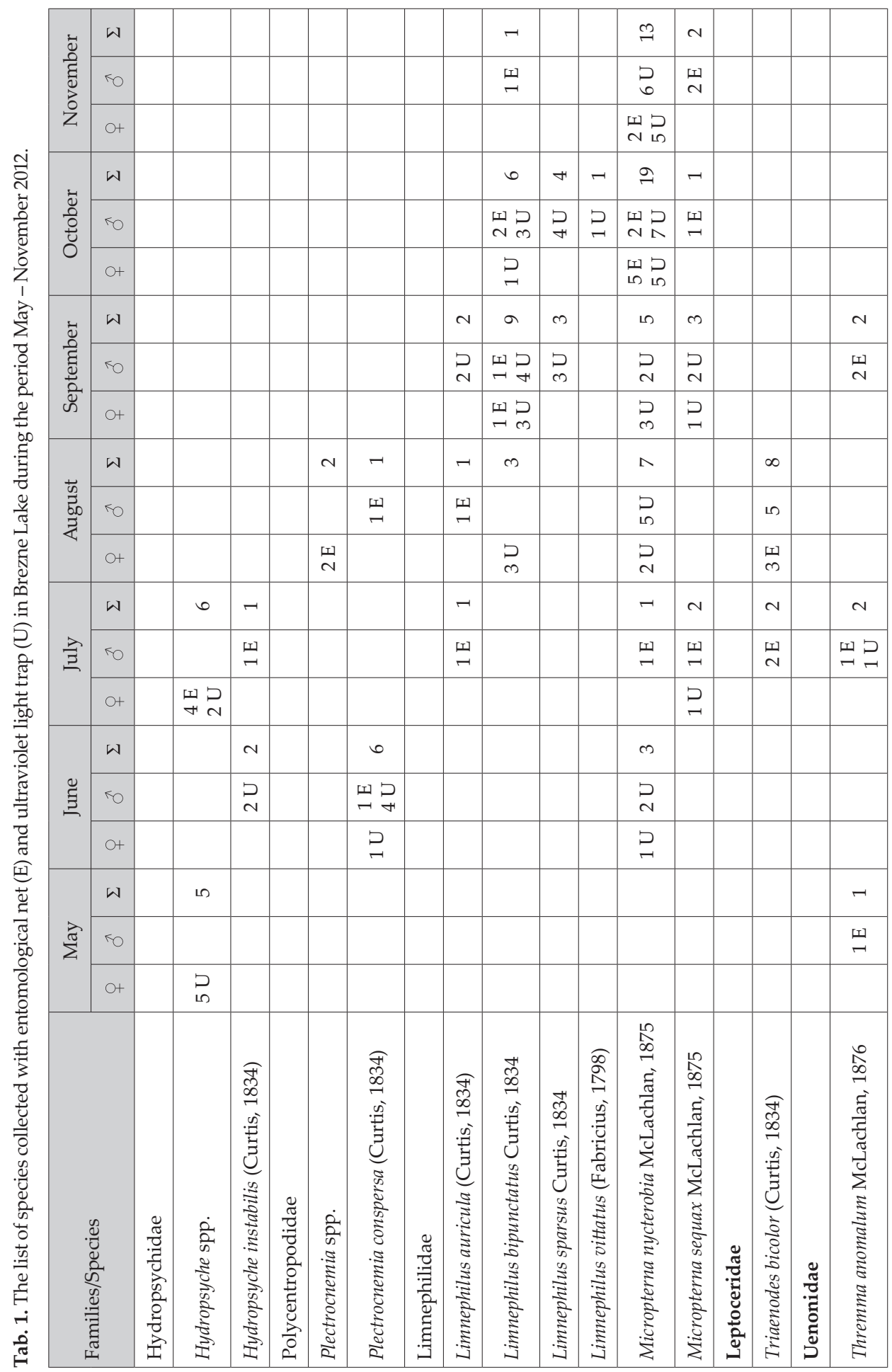


ochreellus (OlÁH \& Kovacs, 2014). According to Fauna Europaea (Malicky, 2013) T. ochreellus is present, as well as in Albania, in Croatia, Montenegro and Serbia. However data for Montenegro and Serbia are not backed by any literature records dealing with the caddisflies of these two countries. Brackish habitats of Croatia are recorded as being inhabited by T. ochreellus lefkas (Kučinić et al., 2015).

Even though Triaenodes bicolor has been reported to emerge from spring to autumn (Graf et al., 2008), during our investigation we found it only at the end of July and in early August although we sampled monthly at Brezne Lake. The reason for this could be the low population density of this species in this area.

This record is a further contribution to the inventory of the caddisfly fauna of the Republic of Kosovo, which is one of the poorest-investigated areas in Europe. This research shows that poorly investigated areas in the Balkan Peninsula will clarify the distribution patterns of rare and less known species of this order of aquatic insects in this area.

\section{ACKNOWLEDGEMENT}

We would like to thank Peter Neu from the Project 'Distributional Atlas of European Trichoptera' (DAET) for providing the map of distribution of Triaenodes bicolor in Europe. We also want to thank two reviewers, Wolfram Graf and Ana Previšić, whose comments significantly improved this manuscript.

Received February 9, 2017

\section{REFERENCES}

DAET, 2017: Distributional Atlas of European Trichoptera. <http://project.freshwaterbiodiversity.eu, accessed at: 2017.05.15>.

Gashi, A. \& Ibrahimi, H., 2008: Spatial and temporal distribution of larvae of Trichoptera in the Mirusha River (Kosovo). Ferrantia 55, 57-60.

Gashi, A., Ibrahimi, H., Grapci-Kotori, L., Sejdiu, N. \& Bislimi, K., 2015: New Records of Drusus siveci Malicky, 1981 (Trichoptera, Limnephilidae, Drusinae) from the Balkan Peninsula, with Ecological Notes. Acta Zoologica Bulgarica 67(2), 259-264.

GAsHi, E., 2014: Ecological and faunistic features of caddisflies (Insecta: Trichoptera) of the Opoja Region (in Albanian). Master Thesis, University of Prishtina, Prishtina: 120 pp.

Graf, W., Murphy, J., Dahl, J., Zamora-Muñoz C. \& López-Rodríguez, J. M., 2008: Trichoptera. In: Distribution and Ecological Preferences of European Freshwater Organisms. Series Ed. Schmidt-KLOIBER, A. \& Hering, D. 1, 1-388.

Higler, B., Spijkers, H. \& van Wielink, P., 2008: A two-year survey of Trichoptera caught on light in the Kaaistoep (The Netherlands). Entomologische Berichten 68(5), 175-181.

Ibrahimi, H., Gashi, A., Bilalli, A., Musliu, M., Grapci Kotori, L. \& Etemi-Zhushi F., 2014a: Three new country records from the genus Limnephilus Leach, 1815 (Trichoptera: Limnephilidae) from the Republic of Kosovo. Biodiversity Data Journal 2, e4140. doi: 10.3897/BDJ.2.e4140

Ibrahimi, H., Gashi, A., Grapci-Kotori, L., Bilalli, A., Musliu, M. \& Etemi-Zhushi, F., 2015a: First record of Mesophylax aspersus (Rambur, 1842) from the Republic of Kosovo (Trichoptera Limnephilidae). Biodiversity Journal 6 (1), 3-6.

Ibrahimi, H., Gashi, A., Grapci-Kotori, L., Zhushi-Etemi, F., Bilalli, A. \& Musliu, M., 2016a: New Distribution and Species Records of Caddisflies (Insecta: Trichoptera) from the Republic of Kosovo. Entomological News 125(4), 229-238.

Ibrahimi, H., Kučinić, M., Gashi, A. \& Grapci Kotori, L., 2014b: Trichoptera Biodiversity of the Aegean and Adriatic Sea basins in Kosovo. Journal of Insect Science 14 (209), 1-8. doi: 10.1093/jisesa/ieu071

Ibrahimi, H., Kučinić, M., Vitecek, S., Graf, W., Previšić, A., Bálint, M., Keresztes, L. \& Pauls, S.U., 2015b: New records for the Kosovo caddisfly fauna with description of a new species, Drusus dardanicus sp. nov. (Trichoptera: Limnephilidae). Zootaxa 4032, 551-568. doi: 10.11646/ zootaxa.4032.5.5

Ibrahimi, H., Previšić, A., Vitecek, S., Graf, W., Kučinić, M., Bálint, M., Keresztes, L. \& Pauls, S.U., 2016b: Drusus sharrensis sp.n. (Trichoptera, Limnerphilidae) a new species from Sharr National Park in Kosovo with molecular and ecological notes. ZooKeys 559, 107-124. doi: 10.3897/zookeys.559.6350 
ILlIES, J., 1967: Limnofauna europaea. Eine Zusammenstellung aller die europäischen Binnengewässer bewohnenden mehrzelligen Tierarten mit Angaben u“ber ihre Verbreitung und O”kologie. Stuttgart: Gustav Fischer Verlag, 474 pp.

Kiss, O., Schmera, D. \& FeHER, I., 2003: Characteristics of caddis larvae assemblages from shallow lakes in the Bükk Mountains, North Hungary. Hydrobiologia 206-509, 365-372.

Kučinić, M., Cerjanec, D., VučKović, I., Mihoci, I., Perović, F., Kutnjak, H., Ibrahimi, H., Pelić Fixa, D., Žalac, S., Mrnjavčić Vojvoda, A. \& PlantaK, M., 2015: Some new and interesting species of caddisflies (Insecta, Trichoptera) found in Croatia. Natura Croatica 24(2), 293-310.

Kučinić, M., Malicky, H., Previšić, A., Vučković, I. Cerjanec, D., Kutnjak, H., Žıvić, I. \& Graf, W., 2012 : First Check List of Caddisflies (Insecta: Trichoptera) of Croatia. XIV International Symposium on Trichoptera, Poster, Vladivostok, Russia.

Kumanski, K., 1985: Trichoptera, Annulipalpia. Fauna Bulgarica 15. Bulgarska Akademi na Naukite, Sofia. 243 pp.

Kumanski, K., 1988: Trichoptera, Integripalpia. Fauna Bulgarica 19. Bulgarska Akademi na Naukite, Sofia. $354 \mathrm{pp}$.

Malicky, H., 2005. Die Köcherfliegen Griechenlands. Denisia 17: 1-240.

Malicky, H., 2004: Atlas of European Trichoptera. 2nd Edition. Springer, Netherlands. 359 pp.

Malicky, H., 2013: Trichoptera. Fauna Europaea version 2017.06, https://fauna-eu.org

Marinković-Gospodnetić, M., 1975: Fauna Trichoptera SR Srbija. Zbornik radova o entomofauni Srbije 1, 219-236.

Marinković-Gospodnetić, M., 1980: Fauna Trichoptera SR Srbija. Zbornik radova o fauni Srbije 1, 71-84.

Marinković-Gospodnetić, M., 1966: New species of Trichoptera from Yugoslavia. Bulletin Scientifique 11, 4-6.

Marinković-Gospodnetić, M., 1970: Descriptions of some species of Trichoptera from Yugoslavia. Annual of the Biological Institute of the University in Sarajevo XXIII, 77-84.

Marinković-Gospodnetić, M., 1971: The species of the genus Drusus in Yugoslavia. Annual of the Biological Institute of the University in Sarajevo XXIV, 105-109.

Marinković-Gospodnetić, M., 1978: The Caddis-Flies (Trichoptera, Insecta) of Hercegovina (Yugoslavia). Annual of the Biological Institute of the University in Sarajevo XXXI, 115-131.

Morse, J.C., 2016: Trichoptera World Checklist. http://entweb.clemson.edu/database/trichopt/, accessed January 27, 2016.

OláH, J., \& Kovács, T., 2014: New species and records of Balkan Trichoptera III. Folia Historico Naturalia Musei Matraensis 38, 97-131.

OlÁH, J., 2016: New Australasian and Oriental Triaenodes species (Trichoptera: Leptoceridae). Opuscula Zoologici Budapest 47(1), 31-63.

Oláh, J., Chvojka, P., Ciubuc, C., Coppa, G. \& Ibrahimi, H., 2015: New incipient species under reinforcement in the Drusus discolor new species complex (Limnephilidae, Trichoptera). Folia Historico-Naturalia Musei Matraensis 39, 105-130.

Oláh, J., Chvojka, P., Coppa, G., Graf, W., Ibrahimi, H., Lodovoci, O., Ruiz-Garcia, A., Sainz-Barain, M., Valle, M. \& Zamora-Munoz, C., 2014: The genus Allogamus Schmid, 1955 (Trichoptera, Limnephilidae): revised by sexual selection-driven adaptive, non-neutral traits of the phallic organ. Opuscula Zoologici Budapest 45(1), 33-82.

St Clair, R. M., 1994: Some larval Leptoceridae (Trichoptera) from southeastern Australia. Records of the Australian Museum 46(2): 171-226.

Stanić-Koštroman, S., 2009: Faunističke, ekološke i biogeografske značajke tulara (Insecta: Trichoptera) Bosne i Herzegovine. PhD Thesis, University of Zagreb, Faculty of Mathematics and Natural Sciences, Zagreb, Croatia, pp 151.

URBANič, G., 2001: Contribution to the knowledge of caddisflies (Trichoptera) of the reservoir Ledavsko Jezeri, NE Slovenia. Acta Entomologica Slovenica 9(2), 129-134.

Žıvić, I, Marković, Z. \& Brajković, M., 2006: Contribution to the faunistical list of Trichoptera (Insecta) of Serbia. Acta Entomologica Slovenica 14 (1), 55-88. 


\title{
SUMMARY
}

\section{First record of Triaenodes bicolor (Curtis, 1834) (Insecta: Trichoptera) from the Ecoregion Hellenic Western Balkans}

\author{
H. Ibrahimi, R. Kuçi, A. Bilalli \& E. Gashi
}

The genus Triaenodes contains nearly 300 species with larvae inhabiting lentic and lotic waters where they are closely associated with the aquatic vegetation. In this paper we report the first record of the genus Triaenodes with the species Triaenodes bicolor from the Republic of Kosovo. This species is reported for the first time from Ecoregion 6, Hellenic Western Balkans, as well. Adult males and females of this species were sampled with entomological net on two occasions, during July and August, in Brezne Lake in Dragash Municipality. No specimen of Triaenodes bicolor was collected with the ultraviolet light trap. In other countries in Europe it has been reported to emerge from spring to autumn. In this locality adult caddisflies were collected monthly with entomological nets and ultraviolet light traps from May to November 2012. Other caddisfly taxa sympatric with Triaenodes bicolor in the investigated locality are: Hydropsyche instabilis, Hydropsyche spp., Plectrocnemia conspersa, Plectrocnemia spp., Micropterna nycterobia, Micropterna sequax, Limnephilus vittatus, Limnephilus auricula and Thremma anomalum. 